\title{
What Factors Affect Middle School Students' Perceptions of Inquiry Learning Towards Science?
}

\author{
Gulsah Sezen Vekli ${ }^{1 \star}$
}

${ }^{1}$ Assoc. Prof. Dr., Department of Science Education, Faculty of Education, Yozgat Bozok University, Yozgat, TURKEY
*Corresponding Author: gulsahsezen28@gmail.com

Citation: Vekli, G. S. (2021). What Factors Affect Middle School Students' Perceptions of Inquiry Learning Towards Science?. Pedagogical Research, 6(4), em0108. https://doi.org/10.29333/pr/11301

\begin{tabular}{|c|c|}
\hline ARTICLE INFO & ABSTRACT \\
\hline Received: 12 Aug. 2021 & This study determines perceptions of middle school students' inquiry learning skills towards science change \\
\hline Accepted: 9 Oct. 2021 & $\begin{array}{l}\text { according to different variables. In line with purpose, it aims to realize what should be done to develop this } \\
\text { perception by questioning the factors that affect students' perceptions of science-related inquiry skills and } \\
\text { contribute to the training of students who question more in science lessons. Based on the survey, the data were } \\
\text { obtained from the Scale of Inquiry Learning Skills Toward Science and the personal information form. These } \\
\text { instruments were applied to } 667 \text { middle school students attending two middle schools. The data were analyzed } \\
\text { statistically by using the Mann-Whitney U and Kruskal-Wallis H tests. It was determined that the perceptions of } \\
\text { middle school students' inquiry learning skills towards science differed according to their gender, grade level, }\end{array}$ \\
\hline
\end{tabular}

Keywords: perceptions, inquiry learning skills towards science, middle school students

\section{INTRODUCTION}

Scientists make inquiries to reach thoughts and theories that will help them explain factual situations they observe. Studies conducted especially recently in relation to science teaching show that inquiring learning environments bears significant importance, and science learning must be done using the query (Bell et al., 2010). In science lessons, students make an inquiry, just like scientists, to understand what is happening around them and understand natural facts. In this way, they improve their understanding of science (Harlen, 2014). When it is considered from this respect, it is seen that having inquiry skills plays a significant role in understanding scientific concepts and to develop a scientific perspective. Hence, in the new science lesson teaching program revised in our country in 2013, a learning approach based on research inquiry was taken as a basis, and improvement of inquiry skill has taken its place among general targets of the program (MEB, 2013).

Dewey defines inquiry skills as asking questions about an event or case desired to be learned and to search for answers, obtaining new information while collecting data, discussing the obtained information, and making reflections (Taşkoyan, 2008). As it can be understood from here, the inquiry process covers processes where the individual is mentally active, and it is required for the individual to have the skill to organize these dense mental activities. However, even though gaining inquiry skills and applying them constitutes one of the important purposes of the science curriculum, the inquiry skill of each student does not develop at the same level. Among the reasons of this situation, inquiry level in learning environments, importance and value attached to inquiry in this environment, students having different goals when participating in learning environments, and students not included in the learning process at the same level can be listed (Feyzioğlu, 2019). Furthermore, according to socio-cognitive learning theory, learning environment, personal features, and relations among behaviors can affect learning (Bandura, 1997). However, most of the studies conducted concerning inquiry skills are limited with examining the impact of different methods and techniques used on inquiry skills. In another way of saying, with regards to improvement of inquiry skill, it was focused on learning environments, and it was not adequately understood what kind of a role the relations between behaviors and features students had on inquiry skill.

It is considered that inquiry skill perceptions being among personal features of students could be effective on improvement of inquiry skills. It can be said that students with high perceptions of inquiry skills will have more efforts towards researching, questioning, discovery, and problem-solving skills, so they may be more advantageous in developing inquiry skills (Kahyaoğlu \& Saraçoğlu, 2018). Examining middle school students' current perceptions of inquiry skills and possible variables affecting this

The abstract of this study was presented at the the 7th International Scientific Research Congress. 
perception can help and guide both teachers and program developers, especially in the context of organizing and planning the learning environment. At this point, this study aims to determine students' perceptions of inquiry learning skills and the factors affecting these perceptions.

When the studies on the perception of inquiry learning skills are examined, it can be said that these studies are grouped under three headings: $i$. Studies examining the effects of different learning methods and techniques on students' perceptions of inquiry learning skills in different age groups. (Balım, 2009; Gormally et al., 2009; Gül et al., 2014; Güngören 2009; Kang et al., 2012; Mahdiannur \& Romadhoni, 2020; Özçelik, 2019; Pedaste \& Sarapuu, 2006; Setiono et al., 2019; Sungur \& Aslan, 2017; Wu \& Hsieh, 2006), ii. Studies in which a scale was developed to determine the inquiry learning skill perceptions of students in different age groups and evaluating students' perceptions of inquiry learning (Aldan-Karademir \& Saracaloğlu, 2013; Balım \& Taşkoyan, 2007; Inal-Ekici, 2017; Şahin et al., 2017; Wu \& Hsieh, 2006;), iii. Studies examining the relationship between students' perceptions of inquiry learning skills and their motivation, attitudes towards science and academic achievement (Feyzioğlu, 2019; Kahyaoğlu \& Saraçoğlu, 2018).

Two studies were found in the literature which examined the factors affecting middle school students' perceptions of inquiry learning skills towards science. Okumuş and Yetkil (2020) examined the inquiry skills of 298 middle school students according to gender and grade level variables. In the study, the Inquiry Skills Scale developed by Aldan Karademir and Saracaloğlu (2013) for teacher candidates was used without a statistical adaptation study. As a result of the research, it was found that as the grade level increased, the students' inquiry skills decreased, while gender did not have a significant effect on their inquiry skills. In another study conducted by Inal-Ekici (2017), some factors affecting the perceptions of inquiry learning skills towards science were examined in 685 middle school students. (gender, grade level, age, science success grades, mother and father education levels, using computers at home, watching children's science programs on TV, and following any scientific journal). As a result of the study, it was determined that middle school students' inquiry learning skill perceptions towards science differed significantly according to their gender, grade level, age, science achievement grades, and mother and father education levels. The study also concluded that middle school students' using computers at home, watching children's science programs on TV, and following any scientific journal are factors that affect their perceptions of inquiry learning skills towards science. To better understand the factors affecting students' inquiry skills, it is necessary to investigate whether the study results are repeatable. Although most of the variables in previous studies are included in this study, the effect of family income on students' inquiry skills will also be examined.

The research problem of this study is "Do inquiry learning skills perceptions of middle school students concerning science change according to different variables such as -their gender, -their class level, -their academic average, -their family income level, -their mother's education status, -their father's education status, -their frequency of using technology?

\section{AIM OF STUDY}

This study aims to determine whether middle school students' perceptions of inquiry learning skills towards science differ according to variables (gender, grade level, academic average, family income level, mother's education level, father's education level, frequency of using technology). In line with this purpose, it aims to question the factors affecting students' perception of inquiry skills towards science, realize what needs to be done to improve this perception, and contribute to the training of students who make more inquiry in science lessons especially in our country.

\section{METHOD}

A survey model was used for this quantitative research study. It is a quantitative research method in which researchers collect information by scanning a sample group or the whole universe to explain the attitudes, views, behaviors, or characteristics. (Creswell, 2017).

\section{Study Group}

Participants consisted of 667 students attending two middle schools in a province in Central Anatolia. The convenience sampling method was used to determine the sample in this study. Table 1 shows the demographic distribution of the students participating in the survey.

The gender of the study participants was examined in two categories as female and male. The class level was examined in four categories as fifth, sixth, seventh, and eighth. Their status of using technology was examined in three categories as rarely, occasionally, and frequently. Their end-of-semester grades were examined in five categories as 1, 2, 3, 4, and 5. Students' parents' educational level was examined in four categories: primary school, secondary school, high school, university, and above. Finally, the family income status was examined in four categories (1000-2000 TL, 2001-4000 TL, 4001-6000, $6001 \mathrm{TL}$, and above).

As shown in Table 1, 342 of the middle school students participating in the research are female students; 325 are male students. When the distribution of students according to their classes is examined, it is seen that 137 fifth grade, 119 sixth grade, 178 seventh grade, and 233 eighth grade students took part in the research. Detailed information on other variables related to participant students is given in Table 1. 
Table 1. Demographic distribution of the middle school students participating in the study

\begin{tabular}{|c|c|c|}
\hline Variables & Groups & $n$ \\
\hline \multirow{2}{*}{ Gender } & Female & 342 \\
\hline & Male & 325 \\
\hline \multirow{4}{*}{ Class levels } & Fifth & 137 \\
\hline & Sixth & 119 \\
\hline & Seventh & 178 \\
\hline & Eighth & 233 \\
\hline \multirow{5}{*}{$\begin{array}{c}\text { End-of-semester } \\
\text { grades }\end{array}$} & 1 & 2 \\
\hline & 2 & 27 \\
\hline & 3 & 105 \\
\hline & 4 & 235 \\
\hline & 5 & 298 \\
\hline \multirow{3}{*}{$\begin{array}{l}\text { Frequency of } \\
\text { students' using } \\
\text { technology }\end{array}$} & Frequently & 100 \\
\hline & Occasionally & 362 \\
\hline & Rarely & 205 \\
\hline
\end{tabular}

\begin{tabular}{ccc}
\hline Variables & Groups & $\boldsymbol{n}$ \\
\hline \multirow{3}{*}{$\begin{array}{c}\text { Educational status of } \\
\text { the mother }\end{array}$} & Primary school & 227 \\
\cline { 2 - 3 } & Secondary school & 173 \\
\cline { 2 - 3 } & High school & 208 \\
\cline { 2 - 3 } & University and upper & 59 \\
\cline { 2 - 3 } Educational status of & Primary school & 105 \\
\cline { 2 - 3 } the father & Secondary school & 143 \\
\cline { 2 - 3 } & High school & 282 \\
\cline { 2 - 3 } & University and upper & 137 \\
\cline { 2 - 3 } Family income level & $1000-2000 \mathrm{TL}$ & 145 \\
\cline { 2 - 3 } & 2001-4000 TL & 287 \\
\cline { 2 - 3 } & 4001-6000 TL & 157 \\
\hline
\end{tabular}

\section{Data Collection Tools}

\section{Personal information form}

The researcher prepared this form to identify the demographic properties of middle school students' gender, grade levels, end of semester grades, family educational status, family income levels, and frequency of using technology.

\section{Perception Scale of Inquiry Learning Skills for Science (PSILESS)}

PSILESS was used in determining middle school students' perception of inquiry skills towards science. It was developed by Balım and Taşkoyan (2007). Survey consists of 22 items and three sub-factors (Positive Perceptions: PP; Negative Perceptions: NP and Perceptions of Accuracy Inquiry: PAI). These items were scaled in five categories being "I completely agree", "I agree", "I am undecisive", "I don't agree" and "I don't agree at all". Positive sentences in the scale are scored as 5, 4, 3, 2, 1, starting with the category of "I completely agree". Among sub-factors in the scale, items measuring positive perceptions are; 3, 4, 8, 9, 15, 16, 19, 20,21 , items measuring negative perceptions are; 2, 6, 10,12,14,17 and items measuring verification inquiry perceptions are items numbered as $1,5,7,11,13,18$ and 22 . The measurement reliability was found to be 0.84 for PSILESS and $0.73,0.67$, and 0.71 for the sub-dimensions of positive perceptions, negative perceptions, and perceptions of accuracy inquiry, respectively (Balım \& Taşkoyan, 2007). The highest score that can be obtained from the scale is 110 ; the lowest score is 0 . In this study, the Cronbach alpha reliability coefficient of the scale was found to be 0.852 .

\section{Data Collection Procedures}

The schools in which the study would be conducted were selected among the schools which the researcher could access easily and in which she could carry out the survey. In the process, all participants were first informed about the study's aim and asked about taking part in the study. During the process, firstly, the teachers who will apply the Personal Information Form and the inquiry learning skill perception scale for science were contacted, and the information they would need about the application of the scale was shared both verbally and in writing via telephone and mail. Middle school students who will apply the scale are presented with the following instruction in the introduction part of the scale:

Dear students,

This scale was developed to determine your perception of inquiry learning skills for a science lesson. The opinions you state here will be used for research purposes only, and the results will be evaluated by considering the responses of the whole group. For the reliability of this research, it bears significant importance that you state your true thoughts. Please do not leave any item blank and give only one answer for each one. While answering the items, you are asked to follow a path like this.

1. Please read each item carefully.

2. Determine how suitable or unsuitable the item you read is for you.

3. Mark one of these options to give a reply.

- I completely agree

- I agree

- I am indecisive

- I don't agree 
- I don't agree at all

I thank you for the contributions you made to this study.

\section{Data Analysis}

The data was analyzed on the Statistical Package for the Social Sciences (SPSS). The value of .05 was considered as the significance level in interpreting the results. Firstly, incomplete data and normality (kurtosis and skewness, Kruskal Wallis Test) were examined, and the data was organized. The data did not have a normal distribution according to the groups; therefore, nonparametric tests were used to analyze the data. Mann Whitney $\mathrm{U}$ test was used in analyzing the PSILESS scores according to gender. The Kruskal Wallis $\mathrm{H}$ test was used in testing whether there were any differences between PSILESS scores according to grade levels, end of semester grades, family educational status, family income levels, frequency of using technology.

\section{FINDINGS}

In this section, the findings of the research are presented under subheadings within the framework of variables.

\section{Gender and Perceptions of Inquiry Learning Skills Towards Science}

Table 2 shows the Mann Whitney $U$ test results for females' and males' positive perceptions, negative perceptions and perceptions of accuracy inquiry scores, and their PSILESS scores.

Table 2. Mann Whitney U test results for participants' PSILESS scores according to gender

\begin{tabular}{|c|c|c|c|c|c|}
\hline Groups & Test statistics & PP & NP & PAI & Total \\
\hline \multirow{5}{*}{$\begin{array}{c}\text { Female } \\
\text { Male }\end{array}$} & \multirow{2}{*}{ Mean rank } & 351.00 & 351.34 & 356.32 & 356.02 \\
\hline & & 316.11 & 315.75 & 310.51 & 310.82 \\
\hline & $U$ & 49760,000 & 49644,000 & 47941,500 & 48043,000 \\
\hline & $p$ & .019 & .016 & .002 & .002 \\
\hline & $\eta^{2}$ & 0.008 & 0.009 & 0.014 & 0.014 \\
\hline
\end{tabular}

PP: Positive Perceptions; NP: Negative Perceptions; PAl: Perceptions of Accuracy Inquiry

Table 2 shows that the students' scores for their positive perceptions $(U=49760,000, p<.05, \eta 2=0.008)$ differed in favor of the female students. The students' scores for their negative perceptions $(U=49644,000, p<.05, \eta 2=0.009)$ differed from the female students. Also, the participants' scores for their perceptions of accuracy inquiry ( $U=47941,500, p<.05, \eta 2=0.002)$, and total PSILESS scores differed in favor of the females significantly $(U=48043,000, p<.05, \eta 2=0.014)$.

\section{Class Levels and Perceptions of Inquiry Learning Skills Towards Science}

Table 3 shows the results of the Kruskal Wallis test for the fifth, sixth, seventh, and eighth graders' positive perceptions, positive perceptions, negative perceptions, and perceptions of accuracy inquiry scores and their total PSILESS scores.

Table 3. Kruskal Wallis test results for PSILESS scores according to the participants' class levels

\begin{tabular}{|c|c|c|c|c|c|}
\hline Groups & Test statistics & PP & NP & PAI & Total \\
\hline 5 & \multirow{2}{*}{ Mean rank } & 374.34 & 367.06 & 367.55 & 374.66 \\
\hline 6 & & 332.79 & 314.35 & 338.80 & 332.89 \\
\hline 7 & & 336.25 & 329.04 & 340.90 & 335.47 . \\
\hline \multirow[t]{4}{*}{8} & & 309.18 & 328.38 & 306.55 & 309.53 \\
\hline & $x^{2}$ & 9.928 & 5.740 & 9.230 & 9.881 \\
\hline & $P$ & .019 & .125 & .026 & .020 \\
\hline & $\eta^{2}$ & 0.01 & 0.004 & 0.009 & 0.001 \\
\hline
\end{tabular}

PP: Positive Perceptions; NP: Negative Perceptions; PAI: Perceptions of Accuracy Inquiry

Table 3 reveals that the students' positive perceptions scores $\left(X^{2}=9.928, p<.05, \eta 2=0.01\right)$, perceptions of accuracy inquiry scores $\left(X^{2}=9.230, p<.05, \eta 2=0.009\right)$ and also total PSILESS scores $\left(X^{2}=9.881, p<.05, \eta 2=0.001\right)$ differed according to class levels. This shows that fifth graders' positive perceptions, perceptions of accuracy inquiry scores, and total PSILESS scores were higher than those of the sixth grade. On the other hand, the students' negative perceptions scores $\left(X^{2}=5.740, p>.05, \eta 2=0.004\right)$ did not differ according to class levels.

\section{End-of-Semester Grades and Perceptions of Inquiry Learning Skills Towards Science}

Table 4 shows the results of the Kruskal Wallis test for the participants' positive perceptions, negative perceptions, and perceptions of accuracy inquiry scores and their PSILESS scores according to their end of semester grades. 
Table 4. The results of the Kruskal Wallis test for participants' PSILESS scores according to their end of semester grades

\begin{tabular}{|c|c|c|c|c|c|}
\hline Groups & Test statistics & PP & NP & PAI & Total \\
\hline 1 & \multirow{2}{*}{ Mean rank } & 131.25 & 174.50 & 274.50 & 166.25 \\
\hline 2 & & 207.46 & 244.06 & 238.33 & 198.70 \\
\hline 3 & & 236.93 & 267.60 & 248.10 & 227.02 \\
\hline 4 & & 298.47 & 296.09 & 316.98 & 296.92 \\
\hline \multirow[t]{4}{*}{5} & & 409.05 & 396.51 & 386.76 & 414.32 \\
\hline & $x^{2}$ & 94.000 & 61.856 & 52.128 & 107.754 \\
\hline & $p$ & .000 & .000 & .000 & .000 \\
\hline & $\eta^{2}$ & 0.136 & 0.087 & 0.073 & 0.157 \\
\hline
\end{tabular}

PP: Positive Perceptions; NP: Negative Perceptions; PAl: Perceptions of Accuracy Inquiry

Table 4 shows that students' scores for positive perceptions $(X 2=94.000, p<.05, \eta 2=0.136)$, negative perceptions $(X 2=61.856$, $\mathrm{p}<.05, \eta 2=0.087)$, perceptions of accuracy inquiry $(X 2=52.128, p<.05, \eta 2=0.073)$, and also their total PSILESS scores (X2=107.754, $\mathrm{p}<.05, \eta 2=0.157$ ) differ according to their end of semester grades. This shows that students have positive perceptions of fifth grades, perceptions of accuracy inquiry scores, and their total PSILESS scores were higher than the others.

\section{Educational Status of Mother and Perceptions of Inquiry Learning Skills Towards Science}

Table 5 shows the results of the Kruskal Wallis test for the participants' positive perceptions, negative perceptions, and perceptions of accuracy inquiry scores and also their PSILESS scores according to their mothers' educational status.

Table 5. The results of the Kruskal Wallis test for participants' PSILESS scores according to their mother's educational status

\begin{tabular}{|c|c|c|c|c|c|}
\hline Type of school & Test statistics & PP & NP & PAI & Total \\
\hline \multirow{3}{*}{$\begin{array}{c}\text { Primary school } \\
\text { Elementary } \\
\text { school }\end{array}$} & \multirow{2}{*}{ Mean rank } & 310.86 & 304.65 & 308.61 & 305.38 \\
\hline & & 319.87 & 321.60 & 326.61 & 317.72 \\
\hline & & 347.01 & 353.29 & 349.82 & 352.01 \\
\hline \multirow{4}{*}{$\begin{array}{l}\text { High school } \\
\text { University }\end{array}$} & & 418.59 & 415.25 & 397.58 & 428.34 \\
\hline & $X^{2}$ & 16.576 & 19.073 & 12.079 & 22.220 \\
\hline & $p$ & .001 & .000 & .007 & .000 \\
\hline & $\eta^{2}$ & 0.02 & 0.024 & 0.014 & 0.029 \\
\hline
\end{tabular}

PP: Positive Perceptions; NP: Negative Perceptions; PAl: Perceptions of Accuracy Inquiry

As shown in Table 5, the students' scores for positive perceptions $\left(X^{2}=16.576, p>05, \eta 2=0.02\right)$, negative perceptions $\left(X^{2}=19.073\right.$, $\mathrm{p}<.05, \eta 2=0.024)$, perceptions of accuracy inquiry scores $\left(X^{2}=12.079, p<.05, \eta 2=0.014\right)$, and also their PSILESS scores $\left(X^{2}=22.220\right.$, $\mathrm{p}<.05, \eta 2=0.029)$ differ according to their mothers' educational status.

\section{Educational Status of Father and Perceptions of Inquiry Learning Skills Towards Science}

Table 6 shows the results of the Kruskal Wallis test for the students' positive perceptions, negative perceptions, and perceptions of accuracy inquiry scores and their PSILESS scores according to their fathers' educational status.

Table 6. The results of the Kruskal Wallis test for participants' PSILESS scores according to their father's educational status

\begin{tabular}{|c|c|c|c|c|c|}
\hline Type of school & Test statistics & PP & NP & PAI & Total \\
\hline \multirow{7}{*}{$\begin{array}{l}\text { Primary school } \\
\text { Elementary } \\
\text { school } \\
\text { High school } \\
\text { University }\end{array}$} & \multirow{2}{*}{ Mean rank } & 312.47 & 288.46 & 313.55 & 300.75 \\
\hline & & 295.45 & 309.94 & 305.03 & 293.87 \\
\hline & & 332.88 & 332.66 & 331.40 & 332.64 \\
\hline & & 393.04 & 396.77 & 385.26 & 404.17 \\
\hline & $x^{2}$ & 19.971 & 23.277 & 14.226 & 27.533 \\
\hline & $p$ & .000 & .000 & .003 & .000 \\
\hline & $\eta^{2}$ & 0.026 & 0.031 & 0.017 & 0.037 \\
\hline
\end{tabular}

PP: Positive Perceptions; NP: Negative Perceptions; PAI: Perceptions of Accuracy Inquiry

Table 6 shows that the students' scores for positive perceptions $\left(X^{2}=19.971, p<.05, \eta 2=0.026\right)$, negative perceptions $\left(X^{2}=23.277\right.$, $\mathrm{p}<.05, \mathrm{\eta} 2=0.031)$, perceptions of accuracy inquiry scores $\left(X^{2}=14.226, p<.05, \eta 2=0.017\right)$, and also their PSILESS scores $\left(X^{2}=27.533\right.$, $\mathrm{p}<.05, \mathrm{\eta} 2=0.037)$ differ according to their fathers' educational status.

\section{Family Income Level and Perceptions of Inquiry Learning Skills Towards Science}

Table 7 shows the results of Kruskal Wallis test for participants' positive perceptions, negative perceptions, and perceptions of accuracy inquiry scores and their PSILESS scores according to the level of family income.

Table 7. The results of the Kruskal Wallis test for participants' PSILESS scores according to their family income level

\begin{tabular}{|c|c|c|c|c|c|}
\hline Income groups & Test statistics & PP & NP & PAI & Total \\
\hline $1000-2000$ & \multirow{2}{*}{ Mean rank } & 296.70 & 262.42 & 299.12 & 275.84 \\
\hline $2001-4000$ & & 338.09 & 345.19 & 342.10 & 343.66 \\
\hline $4001-6000$ & & 348.36 & 355.36 & 347.09 & 353.30 \\
\hline \multirow[t]{4}{*}{ 6001-above } & & 359.40 & 382.90 & 342.67 & 367.75 \\
\hline & $x^{2}$ & 7.814 & 28.708 & 6.170 & 17.914 \\
\hline & $p$ & .050 & .000 & .104 & .000 \\
\hline & $\eta^{2}$ & 0.007 & 0.039 & 0.005 & 0.022 \\
\hline
\end{tabular}

PP: Positive Perceptions; NP: Negative Perceptions; PAl: Perceptions of Accuracy Inquiry 
As revealed by Table 7, the students' positive perceptions $\left(X^{2}=7.814 p>.05, \eta 2=0.007\right)$ and also their perceptions of accuracy inquiry $\left(X^{2}=6.170, p>.05, \eta 2=0.005\right)$ attitude did differently than others according to their family income level. However, the students' scores for negative perceptions $\left(X^{2}=28.708, p<.05, \eta 2=0.039\right)$ and their PSILESS scores $\left(X^{2}=17.914, p<.05, \eta 2=0.022\right)$ did differently than others according to family income level. Thus, in another way, inquiry learning skill perceptions of students having families with high-income level, concerning science are higher.

\section{Frequency of Students' Using Technology and Perceptions of Inquiry Learning Skills Towards Science}

Table 8 shows the results of the Kruskal Wallis test for participants' positive perceptions, negative perceptions, and perceptions of accuracy inquiry scores and their PSILESS scores according to the frequency of using technology.

Table 8. The results of the Kruskal Wallis test for participants' PSILESS scores according to the frequency of students' using technology

\begin{tabular}{|c|c|c|c|c|c|}
\hline $\begin{array}{l}\text { Frequency of following scientific } \\
\text { students' using technology }\end{array}$ & Test statistics & PP & NP & PAI & Total \\
\hline \multirow{6}{*}{$\begin{array}{c}\text { Frequently } \\
\text { Occasionally } \\
\text { Rarely }\end{array}$} & \multirow{2}{*}{ Mean rank } & 295.77 & 296.14 & 285.86 & 281.90 \\
\hline & & 329.90 & 337.13 & 325.15 & 330.59 \\
\hline & & 359.89 & 346.94 & 373.12 & 365.43 \\
\hline & $X^{2}$ & 7.825 & 5.018 & 15.531 & 12.890 \\
\hline & $p$ & .000 & .081 & .020 & .002 \\
\hline & $\eta^{2}$ & 0.009 & 0.005 & 0.02 & 0.016 \\
\hline
\end{tabular}

PP: Positive Perceptions; NP: Negative Perceptions; PAl: Perceptions of Accuracy Inquiry

As shown by Table 8, participants' scores for positive perceptions $\left(X^{2}=7.825, p<.05, \eta 2=0.009\right)$, perceptions of accuracy inquiry scores $\left(X^{2}=15.531, p<.05, \eta 2=0.02\right)$, and their PSILESS scores $\left(X^{2}=12.890, p<.05, \eta 2=0.016\right)$ differ according to frequency of using technology.

Moreover, perceptions of middle school students' inquiry learning skills towards science that rarely uses technology is higher than others. The students' negative perceptions $\left(X^{2}=5.018, p>.05, \eta 2=0.005\right)$ and also their perceptions of accuracy inquiry $\left(X^{2}=15.531, p>.05, \eta 2=0.02\right)$ did not differ according to frequency of using technology.

\section{DISCUSSION, RESULT AND IMPLICATIONS}

The present study revealed that middle school students' inquiry learning skills towards science differed according to their gender, grade level, academic average, family income level, mother education level, father education level, frequency of using technology.

This study showed that the gender of middle school students affected their perceptions of inquiry learning skills towards science. Thus, perceptions of the female students' inquiry learning skills towards science were higher than males. This result is similar to the results acquired from the study conducted by İnal Ekici (2017), indicating that female students have more. As it is also stated by Inal Ekici (2017), this result may be due to the particular that girl students' interest in science, their attention and motivation are at a higher level concerning male students (Yaman \& Dede, 2007; Yılmaz \& Huyugüzel-Çavaş, 2007).

Another finding relating to this study was that the students' perceptions of inquiry learning skills toward science differed as per students' class level. Students' perceptions of inquiry learning skills towards science studying at a low-level grade were higher than those of other students. Inal Ekici (2017), and Okumuş and Yetkil (2020) achieved the same results with this study. The researcher summarizes three factors that can cause this outcome in this way: 1 . Subject content becomes more and more complex depending on grade level; It can cause students to have difficulty in questioning different and abstract concepts. 2. Involving less inquiry-based activities in the learning process due to the complexity of the subject content may lead to this result. 3 . This result may also be since students tend to solve more multiple-choice test-type questions due to their preparation for high school entrance exams and avoid allocating time to inquiry-oriented activities such as experiments and research. Based on the conclusion that students' inquiry learning skills decrease as the grade level rises, the number of inquiry-based activities in the science curriculum can be increased, and their quality can be improved to prevent the decrease in students' perceptions of inquiry learning skills depending on the grade level.

It was found out that the inquiry learning skill perceptions of the middle school students participating in the study were affected by the mother and father education level variables. In other words, it has been determined that the high level of education of the parents affects the perceptions of the inquiry learning skills of middle school students towards science positively. This outcome supports the results of Inal Ekici (2017). The researcher explains this result as mothers and fathers with a high level of education establish better communication with their children, assess them as individuals, answer questions they are curious about and support their questioning in their daily lives. Being unsimilar the other research, this study investigated the effect of family income on middle school students' perceptions of inquiry learning skills towards science. As a result, it was revealed that family income status affected students' perceptions of inquiry learning skills towards science positively. It can be stated that this result supported the previous finding when we anticipated that there would be an increase in the family income level with the increase in the family education level under normal conditions. In the light of these results, it can be suggested that more in-class and extra-curricular activities should be given to improve students' perceptions of inquiry learning skills in schools with low family education and socioeconomic levels (Kahyaoğlu \& Saraçoğlu, 2018). 
According to another result obtained from the study, it was revealed that the academic success of middle school students positively affected their perceptions of inquiry learning skills towards science. In another way, the academic success of students with high perceptions of inquiry learning skills towards science is also higher. This result is similar to the study results of Inal Ekici (2017). The particular that students with high perceptions of scientific inquiry skills can effectively use these skills in the learning process may have enabled them to learn science concepts better and increase their science achievement. As being similar, İnal Ekici (2017) states that personal perceptions of inquiry learning skills and students' academic achievement can be two variables that positively affect each other.

As per the outcome obtained from the study, it was determined that middle school students' level of technology use negatively affected their perceptions of inquiry learning skills towards science. Meaning that as the rate of using technology increased, it was revealed that students' perceptions of inquiry learning skills towards science decreased. However, Inal Ekici (2017) determined that using computers at home by middle school students positively affects students' perceptions of scientific inquiry skills. Hence, this study does not show parallelism with the result obtained from Inal Ekici's study. In the questionnaire belonging to this study, students were asked about the rate of using technology in the context of using computers, tablets, and mobile phones. At this point, the rate of students using tablets and mobile phones other than computers may have negatively affected their perceptions of inquiry learning skills towards science. In his study where he tried to determine attitudes of Z generation concerning digital technology, Erten (2019) revealed that students mostly use the smart mobile phone, tablets, laptop computers and that by using these devices, they realized activities such as listening and downloading music, watching TV, watching video from internet and downloading, to surf in social networks, to surf on the internet. When it is evaluated from this respect, it has been accepted as being understood that as the rate of students using technology for the activities mentioned above other than learning is high, this particular would negatively affect their inquiry learning skill perceptions concerning science. Based on this result, it can be recommended for families to set time limits, especially regarding students' usage of tablets and smartphones. It is thought that the results obtained from the study, which reflects the profile of Turkey, will guide those who form educational policies, program developers, lecturers, and researchers working on science education.

Funding: No funding source is reported for this study.

Declaration of interest: No conflict of interest is declared by author.

\section{REFERENCES}

Aldan Karademir, Ç., \& Saracaloğlu, A. S. (2013). Sorgulama becerileri ölçeğinin geliştirilmesi: geçerlik ve güvenirlik çalışması [The development of inquiry skills scale: Reliability and validity study]. Asian Journal of Instruction, 1(2), 56-65.

Aslan, S. (2017). Learning by teaching: Can it be utilized to develop inquiry Skills? Journal of Education and Training Studies, 5(12), 190-198. https://doi.org/10.11114/jets.v5i12.2781

Balım, A. G. (2009). The effects of discovery learning on students' success and inquiry learning skills. Eurasian Journal of Educational Research, 35, 1-20.

Balım, A. G., \& Taşkoyan, N. (2007). Fene yönelik sorgulayıcı öğrenme becerileri algısı ölçeğinin geliştirilmesi [Developing measurement of inquiry learning skills perception in science]. The Journal of Buca Faculty of Education, 21, 58-63.

Bandura, A (1997). The anatomy of stages of change [Editorial]. American Journal of Health Promotion, 12, 8-10. https://doi.org/10.4278/0890-1171-12.1.8

Bell, T., Urhahne, D., Schanze, S., \& Ploetzner, R. (2010). Collaborative inquiry learning: Models, tools and challenges. International Journal of Science Education, 32, 349-377. http://dx.doi.org/10.1080/09500690802582241

Erten, P. (2019). Z kuşağının dijital teknolojiye yönelik tutumları [The attitudes of the Z generation towards digital technology]. Gümüşhane University Journal of Social Sciences Institute, 10(1), 190-202.

Feyzioğlu, B. (2019). The role of inquiry-based self-efficacy, achievement goal orientation, and learning strategies on secondaryschool students' inquiry skills. Research in Science \& Technological Education, 37(3), 366-392. https://doi.org/10.1080/02635143.2019.1579187

Gormally, C., Brickman, P., Hallar, B., \& Armstrong, N. (2009). Effects of inquiry-based learning on students' science literacy skills and confidence. International Journal for the Scholarship of Teaching and Learning, 3(2), 1-22. https://doi.org/10.20429/ijsotl.2009.030216

Gül, Ş., Özay-Köse, E. \& Konu, M. (2014). Genetik ünitesinin öğretiminde kavram karikatürü kullanımının biyoloji öğretmeni adayları üzerine etkisi [The effect of using concept cartoons in the teaching of genetics unit on biology teacher candidates]. Fen Bilimleri Öğretimi Dergisi, 2(1), 1-22.

Harlen, W. (2014). Helping children's development of inquiry skills. Inquiry in Primary Science Education, 1, 5-19.

İnal Ekici, D. (2017). Ortaokul öğrencilerinin bilimsel sorgulama becerileri algılarını etkileyen faktörlerin incelenmesi [An investigation on the factors affecting the scientific inquiry skills perceptions of secondary students]. Kastamonu Education Journal, 25(2), 497-516.

Kahyaoğlu, M., \& Saraçoğlu, M. (2018). Ortaokul öğrencilerinin bilimsel sorgulama becerileri algılarının, merak, motivasyon ve tutum açısından incelenmesi [Examination of secondary school students' scientific inquiry skills perceptions in term of curiosity, motivation and attitude]. Journal of Computer and Education Research, 6(12), 358-376. https://doi.org/10.18009/jcer.472673 
Kang, N. H., DeChenne, S. E., \& Smith, G. (2012). Inquiry learning of high school students through a problem-based environmental health science curriculum. School Science and Mathematics, 112(3), 147-158. https://doi.org/10.1111/j.1949-8594.2011.00128.x

Mahdiannur, M. A., \& Romadhoni, W. (2020). Evaluation of senior high school students' scientific inquiry skills: A perspective from proposing action and interpreting results. Jurnal Penelitian Pendidikan, 5(2), 80-86. https://doi.org/10.26740/jppipa.v5n2.p8086

MEB. (2013). ilköğretim kurumları (ilkokullar ve ortaokullar) fen bilimleri dersi (3, 4, 5, 6, 7 ve 8. sınıflar) öğretim program [Primary education institutions (primary and secondary schools) science lesson (3, 4, 5, 6, 7 and 8 th grades) curriculum]. MEB Publishing.

Okumuş, S., \& Yetkil, K. (2020). Ortaokul öğrencilerinin sorgulama becerilerinin değerlendirilmesi [Evaluation of inquiry skills of secondary school students]. Journal of Bayburt Education Faculty, 15(30), 508-526. https://doi.org/10.35675/befdergi.740348

Özçelik, H. (2019). Kavram karikatürleri ile desteklenen tahmin et-gözle-açıkla (TGA) yönteminin ortaokul öğrencilerinin sorgulama becerileri, bilimsel süreç becerileri ve kavram öğrenmelerine etkisi [Examining the effect of predict-observe-explain (POE) method supported with concept cartoons on secondary school students' inquiry skills, science process skills and conceptual understanding] (Unpublished master's thesis). Marmara University, Institute of Educational Sciences, Istanbul.

Pedaste, M., \& Sarapuu, T. (2006). Developing an effective support system for inquiry learning in a web-based environment. Journal of Computer Assisted Learning, 22(1), 47-62. https://doi.org/10.1111/j.1365-2729.2006.00159.x

Şahin, Ç., Arcagök, S., Çetin, Ş., Mertol, H., \& Boran, G. (2017). Sınıf öğretmeni adaylarının sorgulama becerilerinin incelenmesi [The investigation of pre-service classroom teachers' inquiry skills]. Gazi Journal of Educational Science, 3(3), 0-5. https://dergipark.org.tr/en/pub/gebd/issue/35209/390673

Setiono, S., Rustaman, N. Y., Rahmat, A., \& Anggraeni S. (2019). Student's inquiry skills and learning achievement in plant anatomy practical work using open-guided inquiry. Journal of Physics: Conference Series, 11572 022089. https://doi.org/10.1088/17426596/1157/2/022089

Sungur, S., \& Güngören, S. (2009). The role of classroom environment perceptions in self regulated learning and science achievement. Elementary Education Online, 8(3), 883-900.

Taşkoyan, N. S. (2008). Fen ve teknoloji öğretiminde sorgulayıcı öğrenme stratejilerinin öğrencilerin sorgulayıı öğrenme becerileri, akademik başarıları ve tutumları üzerindeki etkisi [The effect of inquiry learning strategies on students? skills of inquiry learning, academic success and attitudes] (Unpublished master's thesis). Dokuz Eylül Unıversty, Institute of Educational Sciences, Izmir.

Wu, H. K., \& Hsieh, C. H. (2006). Developing sixth graders' inquiry skills to construct explanations in inquiry-based learning environments. International Journal of Science Education, 28(11), 1289-1313. https://doi.org/10.1080/09500690600621035

Yaman, S., \& Dede, Y. (2007). Öğrencilerin fen ve teknoloji ve matematik dersine yönelik motivasyon düzeylerinin bazı değişkenler açısından incelenmesi [Examination of motivation level of students towards science and mathematics by some variables]. Educational Administration: Theory and Practice, 52(52), 615-638. https://dergipark.org.tr/tr/pub/kuey/issue/10345/126723

Yılmaz, H., \& Huyugüzel-Cavaş, P. (2007). Reliability and validity study of the students' motivation toward science learning (smtsl) questionnaire. ilköğretim Online, 6(3), 430-440. 